\title{
Dietary Intake of Amateur Bodybuilding Athletes Around Polokwane Municipality in Limpopo Province, South Africa
}

\author{
Sylven Masoga ${ }^{1}$, Sefora H. M. Makuse ${ }^{1} \&$ Makoma M. Bopape ${ }^{1}$ \\ ${ }^{1}$ Department of Human Nutrition and Dietetics, University of Limpopo, South Africa \\ Correspondence: Sylven Masoga, Department of Human Nutrition and Dietetics, University of Limpopo, Sovenga \\ 0727, South Africa. Tel: 27-15-268-3376. E-mail: sylven.masoga@ul.ac.za
}

Received: May 5, 2019 Accepted: June 5, 2019 Online Published: July 27, 2019

doi:10.5539/gjhs.v11n9p134 URL: https://doi.org/10.5539/gjhs.v11n9p134

\begin{abstract}
Objective: To determine the dietary intake of amateur bodybuilding athletes around Polokwane municipality in Limpopo Province, South Africa.

Design: This was a descriptive cross-sectional study in which purposive sampling was used to recruit 51 participants out of 65 registered part-time competitive bodybuilders at three training gyms around Polokwane. Dietary information was collected using a modified 24-hour-recall questionnaire on three different days, which was validated by the modified Food Frequency Questionnaire.
\end{abstract}

Settings: The study took place at three gyms that enrolled these part-time athletes, all of whom were registered with the International Federation of Bodybuilding in South Africa (IFBBSA). Data were collected during the off-season period.

Results: Macronutrients: All the athletes consumed energy and carbohydrates below the daily recommendations of the International Society for Sports Nutrition (ISSN) with mean values of $129 \pm 36.7 \mathrm{KJ} / \mathrm{kg}$ and $3.9 \pm 0.9 \mathrm{~g} / \mathrm{kg}$ respectively. Furthermore, $78 \%$ and $94 \%$ of the athletes consumed protein $(1.3 \pm 0.5 \mathrm{~g} / \mathrm{kg})$ and fat $(0.8 \pm 0.4 \mathrm{~g} / \mathrm{kg})$ below the daily recommendations, respectively. Vitamins: Most of the athletes took vitamins $\mathrm{C}(53 \%) ; \mathrm{B}_{1}(82 \%)$ and $\mathrm{B}_{6}(82 \%)$ within the Estimated Average Requirements (EAR) while the intake of vitamins $\mathrm{A}(69 \%)$ and $\mathrm{E}$ (72\%) were below the recommendations. While $88 \%$ of the athletes consumed above the EAR for vitamin $\mathrm{B}_{12}$, only $41 \%$ and $17 \%$ took vitamins $\mathrm{B}_{2}$ and $\mathrm{B}_{6}$ above the Upper Tolerable Limit (UL). Minerals: Most of the athletes consumed phosphorus $(94 \%)$, iron $(88 \%)$, zinc $(78 \%)$, magnesium $(71 \%)$ and selenium $(61 \%)$ within the EAR. The proportions of bodybuilders who consumed minerals below the EAR were $86 \%$ for calcium, $4 \%$ for phosphorus, $10 \%$ for iron, $19 \%$ for zinc, $23 \%$ for magnesium and $37 \%$ for selenium.

Conclusion: The macronutrient intake of bodybuilders around Polokwane is mostly below recommendations, but consumption of micronutrients is mostly within the recommendations. Therefore, the dietary intake of these bodybuilders especially for macronutrient intake is sub-optimal to support their competitive activity.

Keywords: bodybuilding, macronutrient, micronutrient

\section{Introduction}

Optimal dietary intake in sport is associated with improved health during and after both training and performance. Bodybuilders, however, tend to follow different diets, which at times can be unscientifically proven (Helms, Aragon, \& Fitschen, 2014), posing a negative impact on performance and general health. Furthermore, it is noted among this group that, they habitually consume a high-protein diet (normally coupled with a low or high carbohydrate and low or high fat intake) in the belief that it is necessary for muscle growth and repair (Phillips, 2012). This high protein intake can compromise the intake of other macronutrients, fat-soluble vitamins, fruit and vegetables (Guardia, Maurizio, \& Hellas, 2015). Information relating to the dietary intake among the bodybuilders around some parts of South Africa, particularly Gauteng (Barnard, 2012), has been well documented, but there seems to be a lack of published information about the dietary practices of bodybuilding athletes in Limpopo. The researcher observed that the province has a growing number of athletes engaging in bodybuilding sport, most of whom are part-time competitors. Newly emerging bodybuilders may follow diets prescribed by the media, coaches or even fellow athletes (who are not nutrition experts), which predisposes them to poor performance and health problems later in life. Therefore, it is imperative to investigate the dietary intake of these athletes in the case of this 
study in order to encourage adherence to nutrition recommendations so that these athletes can enjoy a lifelong bodybuilding career.

\subsection{Energy}

Total energy intake and the proportion of the energy derived from macronutrients are often planned and implemented to maximize skeletal muscle hypertrophy and minimize body fat (Lankford \& Campbell, 2012). Optimizing training and performance through nutrition should be ensured so that athletes consume enough calories to offset energy expenditure. Energy intakes of 44-50 kcal $/ \mathrm{kg} /$ day among strength athletes are recommended (Slatter \& Phillips, 2011). However, a higher intake of 50-80 kcal $/ \mathrm{kg} /$ day of energy is recommended (Kreider et al., 2010; Potgieter, 2013).

\subsection{Carbohydrates}

During intense exercises, carbohydrate $(\mathrm{CHO})$ becomes the main preferred source of energy. Bodybuilding athletes mostly perform at this level and, therefore, adequate CHO intake is of great importance (Burke et al., 2011). Athletes exercising with low $\mathrm{CHO}$ reserves are often predisposed to increased levels of stress hormones, which may impair the immune system's functional capacities (Maughan, \& Shirreffs, 2012). Therefore, a daily carbohydrate intake of $8-10 \mathrm{~g} / \mathrm{kg} /$ day may be necessary for athletes (Guardia et al., 2015; Kreider, 2010). The timing, amount and type of CHO play a significant role in muscle glycogen synthesis (Lambert, Frank, \& Evans, 2004). Athletes should consume $3-4 \mathrm{~g} / \mathrm{kg}$ or $200-300 \mathrm{~g}$ and $6-8 \%$ of carbohydrates $3-4$ hours before and during performance/exercise respectively (Potgieter, 2013; American Dietetic Association/Dietitians of Canada/American College of Sports Medicine, 2009). The CHO consumed should be of high glycaemic index (GI) in order to achieve blood glucose supply and storage, thereby improving performance.

\subsection{Protein}

Protein recommendations in sport have controversies (Kreider et al., 2010). However, advocacy of protein above the recommended daily allowance (RDA) $(0.8 \mathrm{~g} / \mathrm{kg} /$ day) is common. Higher consumption of $1.2-1.7 \mathrm{~g} / \mathrm{kg} / \mathrm{day}$ is recommended for competitive bodybuilders to maintain muscle mass (Phillips, 2012; Guardia et al., 2015; ADA/DC/ACSM, 2009; Hyerang, Saningun, \& Ryowon, 2011; Phillips \& Van Loon, 2011), whereas lower values of the range are advised for less intensely involved athletes such as those undertaking endurance exercise (Van Heerden, Hall, \& Schonfeldt, 2014). Intake of the upper recommended limit $(2.0 \mathrm{~g} / \mathrm{kg} /$ day $)$ of protein is considered quite safe in individuals with normal renal function. These dietary protein recommendations can generally be met through diet alone. Protein intake that is too high $(>2.0 \mathrm{~g} / \mathrm{kg} /$ day $)$ can produce extra urea, increase the risk of dehydration, and can result in calcium loss. Therefore, exercising individuals should consume up to twice the RDA of protein in their diet, which is $1.4-2.0 \mathrm{~g} / \mathrm{kg} /$ day (Kreider et al., 2010).

\subsection{Dietary Fat}

Although less is known about the role of dietary fat on exercise and performance, a diet high in fat seems to negatively impair high-intensity exercise or performance (Lambert et al., 2004). Dietary fat is needed to assist in the absorption of fat-soluble vitamins, to protect organs, provide insulation to the body and facilitate the provision of substrate for hormone synthesis, as well as for cellular membrane and myelin sheath integrity (Stellingwerff, Maughan, \& Burke, 2012). Fat intake should be adequate to provide the essential fatty acids and fat-soluble vitamins, as well as to help provide adequate energy for weight maintenance (ADA/DC/ACSM, 2009). Therefore, the diet should provide fat of about $25-30 \%$ of TE (Kreider et al., 2010). A diet high in fat, $>30 \%$ of TE seems to impair performance relative to a diet high in carbohydrates and has been associated with a negative effect on health such as obesity and cardiovascular diseases and on performance (Potgieter, 2013; Lambert et al., 2004).

\subsection{Vitamins}

Some vitamins can positively influence performance due to their potent antioxidant properties (Kreider, 2010). Vitamin $\mathrm{C}$ has been associated with the production of L-carnitine, which transports long-chain fatty acids into mitochondria (Lukaski, 2004). The B-vitamins govern the energy producing reactions during metabolism, therefore a need for these vitamins increases proportionally with energy expenditure (Nande, Mudafale, \& Vali, 2009). Niacin is required for energy production and treatment of dyslipidemia through the production of nicotinic acid (Guardia et al., 2015).

\subsection{Minerals}

Mineral intake that is inadequate impairs optimal health and adversely affects sports performance. Among other minerals, iron needs remain high in athletes (Williams, 2005), particularly females as they lose additional iron during menstruation (Smith, Holmes, \& McAllister, 2015). Other losses are through gastrointestinal bleeding, 
heavy sweat, and urinary excretion. Other contributing factors include haemodilution, gastrointestinal losses, and haemolysis usually experienced during stress and repeated injuries (Williams, 2005). Iron is required for metabolic functions including transportation of oxygen in the blood to the tissues serving a crucial role during the performance. Therefore, athletes require adequate amounts ( $8-18 \mathrm{mg} /$ day) of this mineral (Lukaski, 2004; Kreider et al., 2010).

Calcium is another mineral of importance in sports as it may help to manage body composition and to maintain bone mass (Kreider et al., 2010). Calcium intake below the RDA is generally associated with osteoporosis (Williams, 2005; Walberg-Rankin, Edmonds, \& Gwazdauskas, 1993). Athletes who are unable to achieve their recommended dietary intake of calcium, especially females, may greatly benefit from the supplementation of both calcium and vitamin D (Williams, 2005). Therefore, evidence suggests that dietary calcium supplementation up to $1000 \mathrm{mg} /$ day in athletes susceptible to osteoporosis may support bone health (Kreider et al., 2010). Selenium is thought to be a constituent of several enzymes playing an important role in redox reactions. Although the relationship between selenium and sport has not been well reported in the literature, a safe level of $400 \mu \mathrm{g} / \mathrm{day}$ has been recommended. A summary of nutrients recommendations is given in Table 1 (macronutrients) and Table 2 (a) and (b) (vitamins and minerals).

\section{Material Studied}

Fifty-one registered part-time competitive bodybuilders, who trained in gyms around the Polokwane municipality, were purposively sampled. Of these, 49 were males and only two were females. Some of the participants were students at higher education institutions and residing in semi-rural areas of the municipality. All athletes were affiliated members of the bodybuilding society in Limpopo Province.

\section{Area Descriptions}

Polokwane municipality is one of the four districts situated within the Capricorn district. The municipality is the largest of all other municipal areas with a population of 1154673 most of whom are Northern-Sotho speaking.

\section{Methods and Techniques}

\subsection{Data Collection}

We obtained ethical clearance from the MEDUNSA Research and Ethics committee (MREC) before data collection. Consent to participate in the study was sought from both the gym coaches and the athletes. A written consent was also obtained from the participants before the commencement of the study. Data were collected at the gyms before the start of training during the off-season period. A modified 24-hour-recall questionnaire was used to determine in detail the food items consumed the previous day; and the modified food frequency questionnaire (FFQ) to determine the quantities, types and the frequency of consumption of food items. A food model kit from Nasco was also used to assist athletes in estimating portion sizes of consumed food. Researchers assisted the athletes to remember all the food items consumed in that past period through probing and the use of food models. Questions about activities in which the athletes had engaged during the previous day were also enquired to assist athletes in recalling details of food eaten at or before that time. The 24-hour recall information was collected on three different times; on a Monday, Thursday and Sunday, in order to track the difference in eating pattern. The modified FFQ from the National Food Consumption Survey study (2005) was then used to validate the collected 24-hour recall data from the athletes.

\subsection{Data Analysis}

Results were analysed using the SPSS version 23 statistical package. All the descriptive variables were expressed in mean values and standard deviations $( \pm \mathrm{SD})$. Data from the three 24 -hour-recalls were loaded in the MRC Food Finder version 3 in order to determine the nutrient intake. The average of the three recalls was taken and analysed. The one-way ANOVA (for normal distribution) and the Kruskall Wallis (for non-normal distribution) descriptive tests were used. Each athletes' macronutrient intake was then compared to the International Society of Sports Nutrition (ISSN) recommendations (Table 1). Intakes were reported as below, within or above these recommendations. The athletes' micronutrients intake was compared to the recommendations contained in the booklet provided by the nutrition information centre of the University of Stellenbosch. The estimated average requirements (EAR) and the upper tolerable levels (UL) were used to compare the analysed dietary results (Table 2). For accuracy, the FFQ was used to determine the item code and the frequency of the consumption. 
Table 1. Macronutrient recommendation

\begin{tabular}{lll}
\hline Macronutrient & Recommendation/day & Distribution (TE) \\
\hline Energy & $50-80 \mathrm{kcal}(210-336 \mathrm{~kJ}) / \mathrm{kg}$ & \\
Protein & $1.4-2 \mathrm{~g} / \mathrm{kg}$ & $15-20 \%$ \\
Carbohydrates & $8-10 \mathrm{~g}$ & $55-65 \%$ \\
Fat & $0.5-1 \mathrm{~g}$ & $25-30 \%$ \\
\hline
\end{tabular}

Note. $\mathrm{TE}=$ total energy.

Table 2(a). Specific vitamin recommendations

\begin{tabular}{lllll}
\hline Vitamins & Age (years) & Gender & EAR (mg/day) & UL (per day) \\
\hline Vitamin $B_{1}$ & $19-50$ & Male & 1.0 & - \\
\hline \multirow{2}{*}{ Vitamin $B_{2}$} & $19-50$ & Female & 0.9 & - \\
\hline \multirow{2}{*}{ Vitamin $B_{3}$} & $19-50$ & Male & 1.1 & - \\
\hline \multirow{2}{*}{ Vitamin $B_{6}$} & Female & 0.9 & 35 \\
& $19-50$ & Male & 12 & 35 \\
\hline \multirow{2}{*}{ Vitamin $B_{12}$} & & Female & 11 & 100 \\
& $19-50$ & Male & 1.1 & 100 \\
\hline \multirow{2}{*}{ Vitamin C } & Female & 1.1 & - \\
& $19-50$ & Male & $2.0 \mathrm{mg}$ & - \\
\hline
\end{tabular}

Note. $\mathrm{EAR}=$ Estimated average requirements, $\mathrm{UL}=$ tolerable upper intake levels

Table 2(b). Selected mineral recommendations

\begin{tabular}{lllll}
\hline Minerals & Age (years) & Gender & EAR (mg/day) & UL (mg/day) \\
\hline \multirow{2}{*}{ Selenium } & \multirow{2}{*}{$19-50$} & M & 45 & 400 \\
& & F & 45 & 400 \\
\hline \multirow{2}{*}{ Iron } & \multirow{2}{*}{$19-50$} & M & 6.0 & 45 \\
& & F & 8.1 & 45 \\
\hline \multirow{2}{*}{ Calcium } & $19-50$ & M & 800 & 2500 \\
& & F & 800 & 2500 \\
\multirow{2}{*}{ Phosphorus } & $19-50$ & M & $580 \mathrm{~g}$ & $4.0 \mathrm{~g}$ \\
& & F & $580 \mathrm{~g}$ & $4.0 \mathrm{~g}$ \\
\hline
\end{tabular}

Note. $\mathrm{EAR}=$ estimated average requirements; $\mathrm{UL}=$ tolerable upper intake levels; $\mathrm{M}=$ male, $\mathrm{F}=$ female 


\section{Results}

Table 3. Summary of macronutrients intakes of the athletes

\begin{tabular}{llllll}
\hline Analyte & Mean $/ \mathrm{kg} /$ day $( \pm \mathrm{SD})$ & Recommendation $(\mathrm{ISSN}, 2010)$ & Prevalence of inadequate intake $(\%)$ & Min & Max \\
\hline Energy $(\mathrm{kJ})$ & $129.7( \pm 36.7)$ & $210-330 \mathrm{~kJ} / \mathrm{kg} /$ day & 98 & 150.7 & 212.1 \\
Protein $(\mathrm{g})$ & $1.3( \pm 0.5)$ & $1.4-2 \mathrm{~g} / \mathrm{kg} /$ day & 78 & 0.1 & 2.5 \\
$\mathrm{CHO}(\mathrm{g})$ & $3.9( \pm 0.9)$ & $8-10 \mathrm{~g} / \mathrm{kg} /$ day & 100 & 0.7 & 5.9 \\
Fat $(\mathrm{g})$ & $0.8( \pm 0.4)$ & $0.5-1 \mathrm{~g} / \mathrm{kg} /$ day & 94 & 0.2 & 2.1 \\
\hline
\end{tabular}

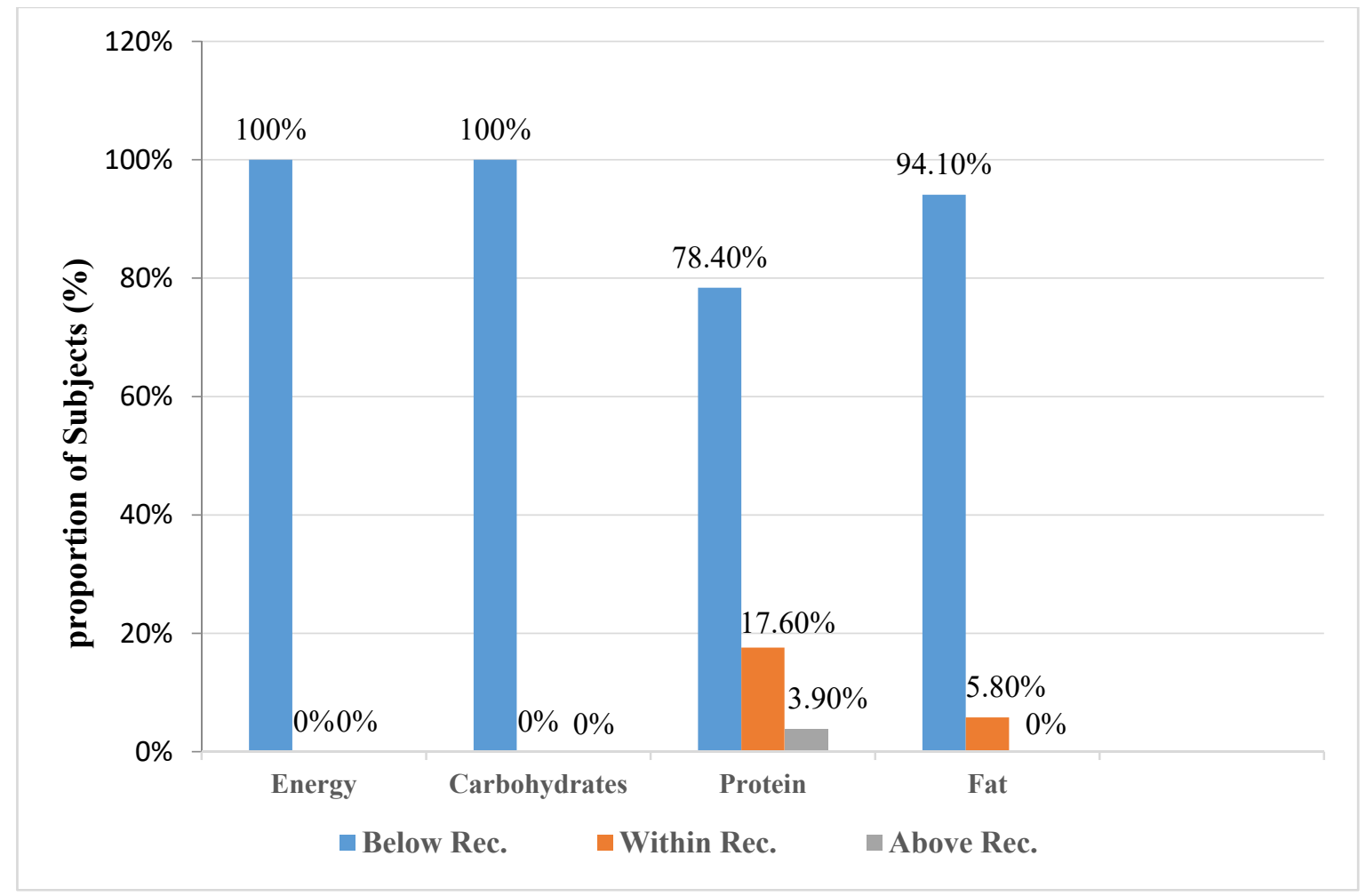

Note. Rec $=$ Recommendation

Figure 1. Macronutrient intake of athletes 
Table 4(a). Summary of vitamin intake of the athletes

\begin{tabular}{|c|c|c|c|c|c|c|c|}
\hline Analyte & Gender & Mean $( \pm \mathrm{SD})$ & $\begin{array}{l}\text { EAR } \\
(\mathrm{mg})\end{array}$ & $\begin{array}{l}\text { UL } \\
(\mathrm{mg})\end{array}$ & $\begin{array}{l}\text { Prevalence of } \\
\text { inadequate Intake } \\
(\%)(n=51)\end{array}$ & Min & Max \\
\hline \multirow{2}{*}{ Thiamine (mg) } & Male & $1.6( \pm 1.6)$ & 1.0 & - & \multirow{2}{*}{11.6} & \multirow{2}{*}{0.5} & \multirow{2}{*}{12.0} \\
\hline & Female & $1.0( \pm 0.2)$ & 0.9 & - & & & \\
\hline \multirow{2}{*}{ Riboflavin (mg) } & Male & $1.5( \pm 0.9)$ & 1.1 & - & \multirow{2}{*}{41.1} & \multirow{2}{*}{0.2} & \multirow{2}{*}{4.9} \\
\hline & Female & $1.0( \pm 0.3)$ & 0.9 & - & & & \\
\hline \multirow{2}{*}{ Niacin (mg) } & Male & $27.4( \pm 15.8)$ & 12 & 35 & \multirow{2}{*}{15.6} & \multirow{2}{*}{1.1} & \multirow{2}{*}{82.4} \\
\hline & Female & $23.7( \pm 15.4)$ & 11 & 35 & & & \\
\hline \multirow{2}{*}{ Vitamin $B_{6}(m g)$} & Male & $1.8( \pm 1.5)$ & 1.1 & 100 & \multirow{2}{*}{17.6} & \multirow{2}{*}{0.6} & \multirow{2}{*}{10.8} \\
\hline & Female & $1.4( \pm 0.8)$ & 1.1 & 100 & & & \\
\hline \multirow{2}{*}{$\begin{array}{l}\text { Vitamin } \mathrm{B}_{12} \\
(\mathrm{mcg})\end{array}$} & Male & $13.5( \pm 37.9)$ & 2.0 & - & \multirow{2}{*}{0.0} & \multirow{2}{*}{0.5} & \multirow{2}{*}{239.0} \\
\hline & Female & $5.2( \pm 4.0)$ & 2.0 & - & & & \\
\hline \multirow{2}{*}{ Vitamin C (mg) } & Male & $85.2( \pm 68.3)$ & 75 & 2000 & \multirow{2}{*}{47.0} & \multirow{2}{*}{2.0} & \multirow{2}{*}{277.0} \\
\hline & Female & $112.3( \pm 101.8)$ & 60 & 2000 & & & \\
\hline
\end{tabular}

Note. $\mathrm{EAR}=$ estimated average requirements, $\mathrm{UL}=$ upper tolerable limit.

Table 4(b). Summary of mineral intake of the athletes

\begin{tabular}{|c|c|c|c|c|c|c|c|}
\hline Analyte (mg) & Gender & Mean $( \pm \mathrm{SD})$ & EAR & UL & $\begin{array}{l}\text { Prevalence of } \\
\text { inadequate Intake } \\
(\%)(n=51)\end{array}$ & Min & Max \\
\hline \multirow{2}{*}{ Calcium } & Male & $580.1( \pm 355.3)$ & 800 & 2500 & \multirow{2}{*}{86.3} & \multirow{2}{*}{0.10} & \multirow{2}{*}{1601.00} \\
\hline & Female & $477.6( \pm 146.1)$ & 800 & 2500 & & & \\
\hline \multirow{2}{*}{ Iron } & Male & $173.3( \pm 4.1)$ & 6.0 & 45 & \multirow{2}{*}{9.8} & \multirow{2}{*}{4.30} & \multirow{2}{*}{295.00} \\
\hline & Female & $9.9( \pm 2.6)$ & 8.1 & 45 & & & \\
\hline \multirow{2}{*}{ Phosphorus } & Male & $1455.7( \pm 489.8)$ & 580 & 4.0 & \multirow{2}{*}{3.9} & \multirow{2}{*}{395.0} & \multirow{2}{*}{2487.00} \\
\hline & Female & $1315.0( \pm 451.0)$ & 580 & 4.0 & & & \\
\hline \multirow{2}{*}{ Selenium } & Male & $52.1( \pm 26.1)$ & 45 & 400 & \multirow{2}{*}{37.3} & \multirow{2}{*}{6.00} & \multirow{2}{*}{120.60} \\
\hline & Female & $47.8( \pm 2.3)$ & 45 & 400 & & & \\
\hline
\end{tabular}

Note. $\mathrm{EAR}=$ estimated average requirements, $\mathrm{UL}=$ upper tolerable limit. 


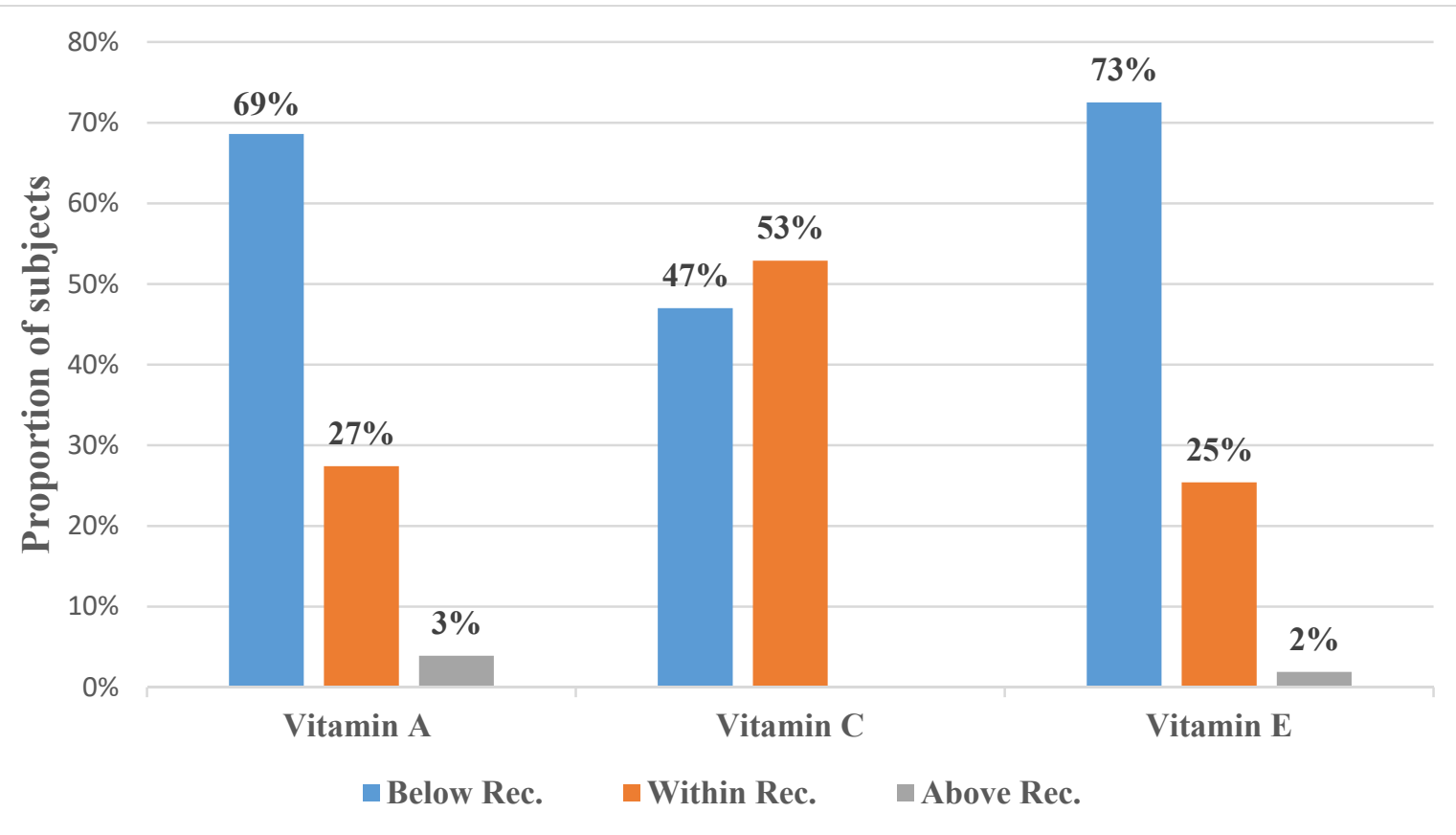

Note. Rec $=$ Recommendation.

Figure 2: Vitamins intake of athletes

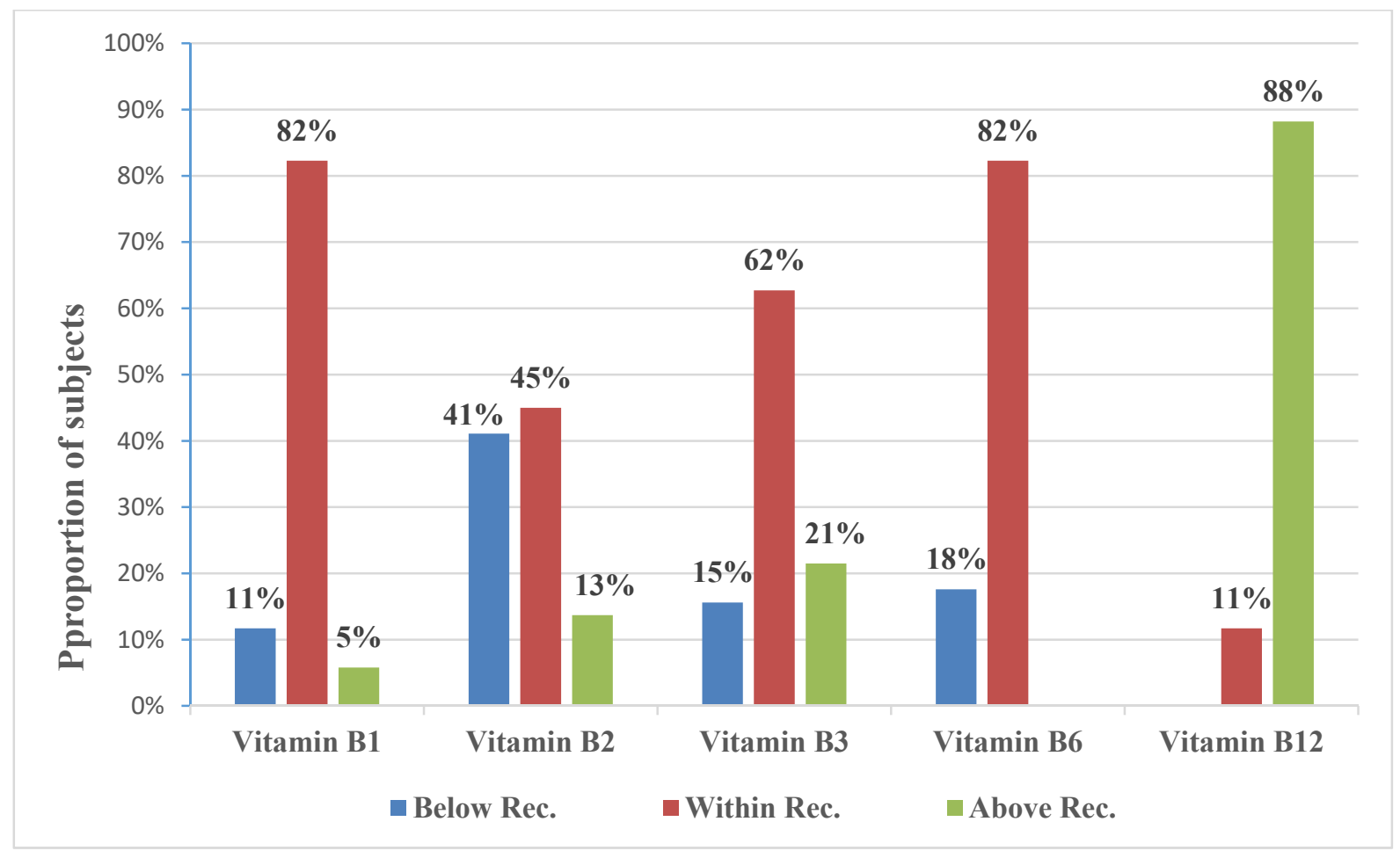

Note. $\mathrm{Rec}=$ Recommendation.

Figure 3. B-vitamin intake of athletes 


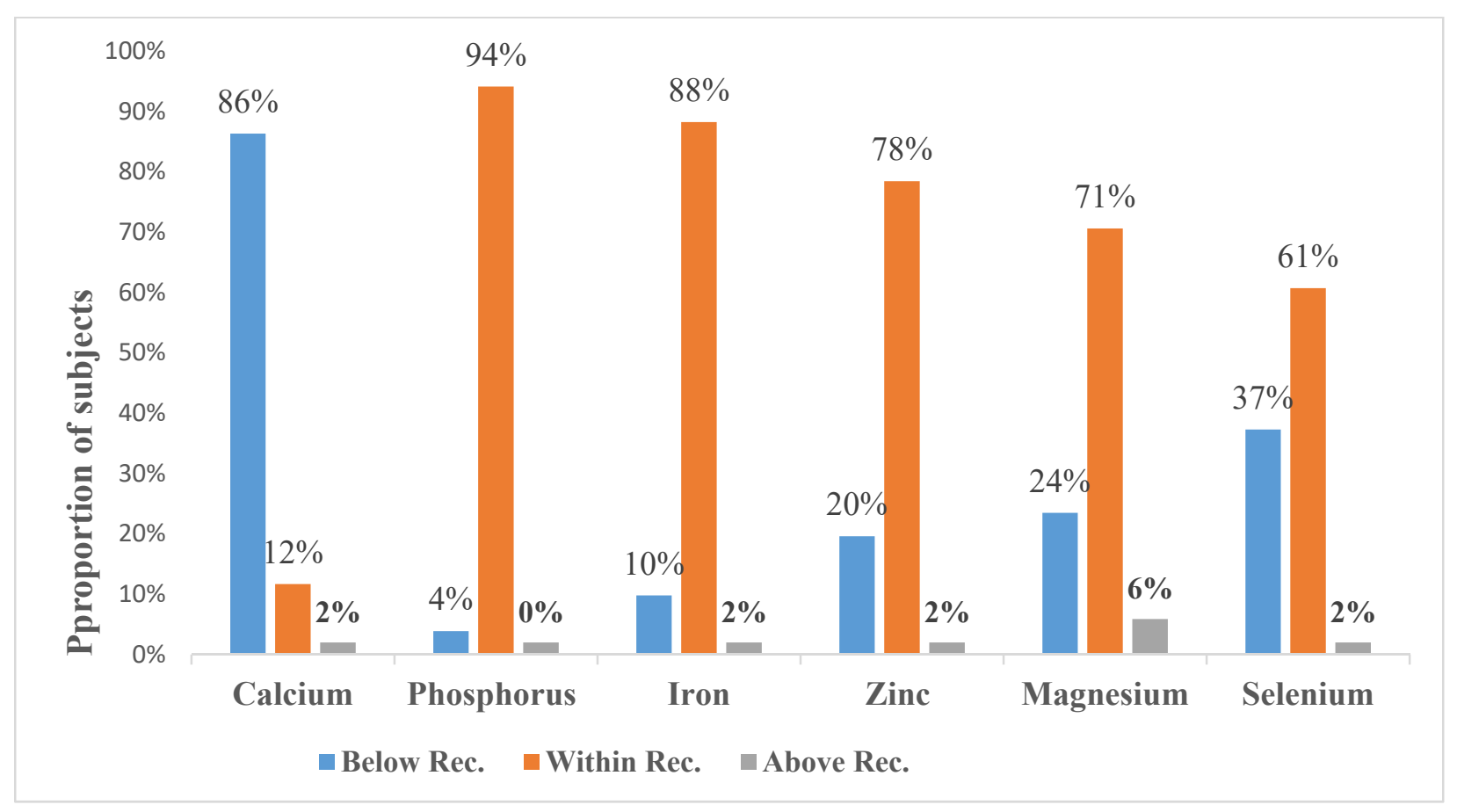

Note. Rec $=$ Recommendation.

Figure 4. Mineral intake of athletes

\section{Discussion}

\subsection{Energy and Carbohydrates}

Almost all of the athletes in the current study consumed energy and CHO below the ISSN recommendations. The mean energy and carbohydrates intake by the athletes was $9010 \mathrm{~kJ}(2145 \mathrm{kcal}) / \mathrm{day}$ and $277.5 \mathrm{~g} /$ day, respectively. The results of this study are comparable to findings of intakes below the recommendations among bodybuilders as reported by other researchers (Monteiro, Pimentel, \& Sousa, 2012). These researchers believe that key reasons for low intake in this group may be lack of proper nutrition education, socioeconomic background and the myth that low energy intakes increase body mass. Lower than recommended energy and carbohydrate intakes are associated with decreased sports performance (Slatter, 2011), weight loss, a compromised immune system, endocrine dysfunctions and, ultimately, low bone mineral density (Potgieter, 2013). Adequate intakes of energy, particularly from carbohydrates is important in preventing oxidation of amino acids. However, in other cases, some researchers have reported higher intakes of energy $(23940 \mathrm{~kJ} /$ day) among the athletes in their studies (Hyerang et al., 2011; Spendlove et al., 2015). It is suspicious that the intake of all the athletes in the current study should fall below the bodybuilding recommendations. One reason could be the under-reported intakes during dietary data collection. It is generally known that starchy foods are a common staple food around Polokwane area, therefore, it is not impossible that athletes might have under-reported their starchy food intake. In addition, given that they came from historically disadvantaged communities, their low socioeconomic background could be regarded as another contributing factor to the below recommendation intake.

\subsection{Protein}

Most of the athletes consumed protein below the recommended levels and a few took protein above the recommendations. The mean protein intake for the athletes was $95.6 \mathrm{~g}$ /day with the minimum and maximum intake of $4.0 \mathrm{~g} /$ day and $177.7 \mathrm{~g}$ /day respectively. Intakes of protein that are below recommendations can result in a negative nitrogen balance, adversely affecting performance and further slowing recovery. When athletes are in a negative nitrogen balance, they can experience muscle catabolism thereby resulting in loss of muscle mass and negatively affecting performance (Kreider et al., 2010). Sub-optimal amounts of protein intake could be due to under-reported dietary data or fear about disclosing the use of protein supplements. These results are different from those reported among the male bodybuilders, who consumed high amounts of protein in their diets (Monteiro et al., 2013). 


\subsection{Dietary Fat}

Relatively few athletes consumed fat within the guidelines. The mean fat intake of the athletes in the current study was $59.2 \mathrm{~g}$ /day. Food containing fat such as margarine and oils were consumed less and appeared very low on the list of the food frequently consumed. These results differ from those reported in a review by other researchers who reported intakes ranging from 19-241 g/day by athletes (Kreider et al., 2010). Fat is necessary for providing energy and essential elements of cell membranes and regulates the absorption of fat-soluble vitamins (ADA/DC/ACSM, 2009). A lower intake of dietary fat may, therefore, result in hormonal disturbances, essential fatty acids deficiencies, and fat-soluble vitamin deficiencies; resulting in a negative impact on the athlete's health (Potgieter, 2013).

\subsection{Vitamins}

Most athletes in the current study consumed less vitamin $\mathrm{E}$ and $\mathrm{C}$, which might have been influenced by the inadequate intake of fruit and vegetables as reflected in the FFQ. Results reported in a review of 22 surveys by Lukaski (2004), reported slightly differing findings, where athletes were reported to consume sufficient amounts of vitamin E. Athletes in this review, consumed sufficient amounts. Vitamin E intakes that do not exceed the UL have been associated with reduced lipid peroxidation. Individual micronutrients intake deficit of vitamin A, C, $B_{12}$ and folate were reported among female bodybuilders' pre-competition diet (Walberg-Rankin et al., 1993). Due to increased losses and oxidation of micronutrients during routine exercise, intakes should be adequate to facilitate processes of energy production, hemoglobin synthesis, maintenance of bone health and immune function, and minimise oxidative damage (ADA/DC/ACSM, 2009). It appeared in the current study that athletes took less of dietary fat, maybe in an attempt to reduce the total body fat percentage. Reduced intake of dietary fat might contribute to the lower intakes or even absorption of fat-soluble vitamins. The FFQ further revealed that fat and oil-containing foods such as margarine and cooking oil mostly appeared last on the list of the food items and were mostly consumed less than three times in a week.

\subsection{Minerals}

Most athletes consumed minerals within the recommended dietary intakes. These adequate intakes were reported for phosphorus, iron, zinc, magnesium, and selenium. Of all the minerals, calcium was the least consumed. In another study, up to $50 \%$ of the athletes were reported to consume magnesium in inadequate amounts (Lukaski, 2004). The athletes can relate the low intake of calcium in the current study to the infrequent intake of milk and other dairy products. Milk as a food source rarely appeared on the athletes' frequently consumed foods. In those athletes who consumed milk, the intake was inadequate. Adequate intake of minerals should be obtained as they play an important physiological role in athletes like muscle contraction, antioxidant activity and bone health (Williams, 2005).

\section{Conclusion and Recommendations}

The aim of this study was to determine the dietary intake among adult bodybuilding athletes around Polokwane Municipality. We found that average macronutrient intake of this group of athletes was mostly below the established international bodybuilding dietary recommendations, whereas the micronutrient intake was overall within the recommendations. The athletes were keeping healthy but inadvertently undermining their longer-term physical conditions, as their intakes were predisposing them to health risks. Therefore, relevant practical support could be made available in gyms in the form, for instance of a dedicated medical team including a dietitian to monitor and guide the athletes on dietary intakes. Regular workshops and awareness activities could be offered to athletes at gyms regarding the role and risks posed by under-and/or over-nutrition on health and performance. Furthermore, regular quarterly medical assessments of liver and kidney function in particular should be actively encouraged.

\section{Acknowledgements}

Bodybuilding athletes who participated in this study.

\section{Competing Interests Statement}

The authors declare that there are no competing or potential conflicts of interest.

\section{References}

American Dietetic Association/Dietitians of Canada/American College of Sports Medicine. (2009). Position of the American Dietetic Association Dietitians of Canada, and the American College of Sports Medicine: Nutrition and Athletic Performance. Journal of American Dietetic Association, 109, 509-527. https://doi.org/10.1016/j.jada.2009.01.005 
Barnard, R. (2012). Body composition and blood measurements of elite senior South African bodybuilders during a competitive season. (Masters Dissertation). The University of the Free State, Bloemfontein, South Africa. Retrieved 25 March, 2019 from http://hdl.handle.net/11660/657

Burke, L. M., Hawley, J. A., Wong, S. H. S., \& Jeukendrup, A. E. (2011). Carbohydrates for training and competition. Journal of Sports Sciences, 29(sup1), S17-S27. https://doi.org/10.1080/02640414.2011.585473

Guardia, D., Maurizio, C., \& Hellas, C. (2015). The risks of self-made diets: The case of an amateur bodybuilder. Journal of the International Society of Sports Nutrition, 12, 16. https://doi.org/10.1186/s12970-015-0077-8

Helms, E. R., Aragon, A. A., \& Fitschen, P. (2014). Recommendations for natural bodybuilding contests preparation; resistance and cardiovascular training. Journal of the International Society of Sports Nutrition, 11, 20. https://doi.org/10.1186/1550-2783-11-20

Hyerang, K., Saningun, L., \& Ryowon, C. (2011). Metabolic responses to high protein diet in Korean elite bodybuilders with high-intensity resistance exercise. Journal of the International Society of Sports Nutrition, 8, 10. https://doi.org/10.1186/1550-2783-8-10

Kreider, B. R., Wilborn, D. C., Taylor, L., Campbell, B., Almada, L. A., Collins, R., ... Antonio, J. (2010). Exercise \& Sport Nutrition Review; Research \& recommendations. International Society of Sports Nutrition, 7, 7. https://doi.org/10.1186/1550-2783-7-7

Lambert, P. L., Frank, L. L., \& Evans, W. J. (2004). Macronutrient considerations for the sport of bodybuilding. Sports Medicine, 34(5), 317-327. https://doi.org/10.2165/00007256-200434050-00004

Lankford, B., \& Campbell, I. B. (2012). Self-reported energy intake of male \& female bodybuilders in the scientific literature. Journal of the International Society of Sports Nutrition, 9(1). 19. https://doi.org/10.1186/1550-2783-9-S1-P19

Lukaski, H. C. (2004). Vitamin and mineral status: Effects on physical performance (review article). Nutrition, 20, 632-644. https://doi.org/10.1016/j.nut.2004.04.001

Maughan, R. J., \& Shirreffs, S. M. (2012). Nutrition for sports performance: Issues and opportunities. Proceedings of the Nutrition Society, 71, 112-119. https://doi.org/10.1017/S0029665111003211

Monteiro, J. C. V., Pimentel, G. D., \& Sousa, M. V. (2012). Relationship between body mass index with dietary fiber intake and skinfolds-differences among bodybuilders who train during morning and nocturne period. Nutricia Hospitals, 27(3), 929-935. https://doi.org/10.3305/nh.2012.27.3.5578

Nande, V., Mudafale, P., \& Vali, S. (2009). Micronutrient status of male \& female players engaged in different sports disciplines. Journal of Exercise Science and Physiotherapy, 5(1). 1-13. Retrieved Jun 3, 2019, from https://search.informit.com.au/documentSummary;dn=857592318298859;res=IELHEA

Phillips, S. M., \& Van Loon, L. J. C. (2011). Dietary protein for athletes: From requirements to optimum adaptation. Journal of Sports Sciences, 29(Sup1), S29-S38. https://doi.org/10.1080/02640414.2011.619204

Phillips, S. M. (2012). Dietary protein requirements and adaptive advantages in athletes. British Journal of Nutrition, 108, S158-S167. https://doi.org/10.1017/S0007114512002516

Potgieter, S. (2013). A review of the latest guidelines for exercise and sports nutrition from the American College of Sport Nutrition, The International Olympic Committee \& the International Society for Sports Nutrition. South African Journal of Clinical Nutrition, 26(1). 6-16. Retrieved from http://sajcn.co.za/index.php/SAJCN/article/view/685

Slatter, G., \& Phillips, M. S. (2011). Nutrition guidelines for strength sports: Sprinting, weightlifting, throwing events, and bodybuilding. Journal of Sports Sciences, 29(Sup1), S67. https://doi.org/10.1080/02640414.2011.574722

Smith, J. W., Holmes, M. E., \& McAllister, M. J. (2015). Nutritional considerations for young athletes (Review article). Journal of sports medicine, 1-8. https://doi.org/10.1155/2015/734649

Spendlove, J., Mitchell, L., Gifford, J., Hackett, D., Slater G., Cobley, S., \& O’Connor, H. (2015). Dietary intake of competitive bodybuilders. Sports Medicine, 45 (7). 1041-1063. https://doi.org/10.1007/s40279-015-0329-4

Stellingwerff, T., Maughan, J. R., \& Burke, M. L. (2011). Nutrition for power sports: Middle-distance running, track cycling, rowing, canoeing/kayaking, and swimming. Journal of Sports Sciences, 29(1). S79-S89. https://doi.org/10.1080/02640414.2011.589469

Van Heerden, I. V., Hall, N. \& Schonfeldt, H. C. (2014). Red Meat in Nutrition and Health (Supplementary chapter, 
Red meat and Sports), 7-8. https://www.cookingwithlamb.com/s/Red-Meat-and-Sport-h9pw.pdf

Walberg-Rankin, J., Edmonds, E. C., \& Gwazdauskas, F. C. (1993). Diet and weight changes of female bodybuilders before and after the competition. International Journal of Sports Nutrition, 3, 87-102. https://doi.org/10.1123/ijsn.3.1.87

Williams, M. H. (2005). Dietary supplements and sports performance: Minerals. Journal of the International Society of Sports Nutrition, 2(1). 43-49. https://doi.org/10.1186/1550-2783-2-1-43

\section{Copyrights}

Copyright for this article is retained by the author(s), with first publication rights granted to the journal.

This is an open-access article distributed under the terms and conditions of the Creative Commons Attribution license (http://creativecommons.org/licenses/by/4.0/). 